\title{
PENERAPAN MODEL PEMBELAJARAN KOOPERATIF TIPE NUMBERRED HEAD TOGETHER (NHT) UNTUK MENINGKATKAN HASIL BELAJAR IPA
}

\author{
Ni Putu Suarmini ${ }^{1}$, Desak Putu Parmiti² \\ 1,2Jurusan Pendidikan Guru Sekolah Dasar, Fakultas IImu Pendidikan \\ Universitas Pendidikan Ganesha Singaraja, Indonesia \\ e-mail: nptsuarmini@yahoo.com,dp-parmiti@undiksha.ac.id
}

\begin{abstract}
Abstrak
Penelitian ini bertujuan untuk mengetahui peningkatan hasil belajar IPA siswa kelas IV SD No. 2 Mengwi tahun pelajaran 2016/2017 setelah diterapkannya model pembelajaran kooperatif tipe Numbered Head Together. Penelitian ini adalah penelitian tindakan kelas yang dilaksanakan dalam dua siklus. Subjek penelitian ini adalah siswa kelas IV SD N 2 Mengwi yang berjumlah 26 orang terdiri dari 15 orang laki - laki dan 11 orang perempuan. Data tentang hasil belajar siswa diperoleh dengan menggunakan metode tes. Setelah data dalam penelitian ini diperoleh, selanjutnya data dianalisis menggunakan metode deskriptif kuantitatif. Hasil yang diperoleh adalah Pada siklus I ketuntasan belajar siswa mencapai 75,38\% , dengan rata-rata hasil belajar siswa sebesar 75,38. Dari siklus I ke siklus II ketuntasan belajar siswa mengalami peningkatan sebesar 5,96\% yaitu $81,34 \%$ dengan rata-rata hasil hasil belajar siswa sebesar 81,34 . Maka dapat dinyatakan bahwa penerapan model pembelajaran kooperatif tipe numbered head together dapat meningkatkan hasil belajar IPA siswa kelas IV SD N 2 Mengwi.
\end{abstract}

Kata Kunci :pembelajaran, kooperatif tipe NHT, hasil belajar

\begin{abstract}
This study aimed to determine the learning outcomes improvement of science subject fourth grade students SD N 2 Mengwi academic year 2016/2017, after the implementation of cooperative learning model Numbered Head Together.This study was a classroom action research conducted in two cycles. The subjects were fourth grade students SD N 2 Mengwi totaling 26 people consisting of 15 men and 11 women. Data on students learning outcomes obtained using test. After the data in this study was obtained, then the data were analyzed using descriptive quantitative method.The result in the first cycle of students' mastery learning reached $75,38 \%$, with an average of the learning outcomes 75.38. From the first cycle to the second cycle of mastery learning students has increased by $5,96 \%$, reached $81,34 \%$ with the average of the learning outcomes 81.34. It can be stated that the implementation of cooperative learning model Numbered head together can improve students learning outcomes of science subject fourth grade students SD N 2 Mengwi.
\end{abstract}

Keywords: learning, cooperative NHT, learning outcomes

\section{PENDAHULUAN}

Pendidikan yang berkualitas merupakan salah satu faktor yang menentukan sumber daya manusia (SDM) yang berkualitas. Kualitas pendidikan bermuara pada kualitas pembelajaran. Kualitas proses pembelajaran mempunyai peran strategis untuk menghasilkan kualitas SDM yang bermutu. Perubahan kurikulum secara periodik merupakan salah satu upaya pemerintah untuk meningkatkan mutu. Perkembangan sains dan teknologi serta tantangan globalisasi perlu disikapi sejak dini. Kurikulum Tingkat Satuan Pendidikan adalah kurikulum operasional yang disusun dan diterapkan oleh tiaptiap satuan pendidikan. Dengan diberlakukannya kurikulum tingkat satuan pendidikan, setiap satuan pendidikan 
diberikan keleluasaan dalam menyusun kurikulumnya yang disesuaikan dengan potensi - potensi yang ada di setiap satuan pendidikan tersebut.

Dalam KTSP, pembelajaran tidak bersifat teacher centered (berpusat pada guru) melainkan bersifat student centered (berpusat pada siswa). Tugas dan peran guru tidak hanya sebagai pemberi informasi, tetapi juga sebagai pendorong belajar agar siswa dapat mengkonstruksi sendiri pengetahuannya melalui berbagai aktivitas pembelajaran yang menuntut siswa berperan aktif.

Pembelajaran yang bersifat student centered dapat ditemukan dalam modelmodel pembelajaran inovatif. Modelmodel pembelajaran inovatif dapat meningkatkan hasil belajar salah satunya dengan model pembelajaran kooperatif (Arini, 2009; Dimyanti \& Mudjiono, 1992). Model pembelajaran kooperatif adalah suatu strategi untuk mencapai tujuan bersama yang melibatkan kelompok kelompok kecil yang heterogen dan saling ketergantungan (Santyasa dan Sukadi, 2009; Hakim, 2008). Dengan adanya model pembelajaran kooperatif ini guru diharapkan dapat mencapai tujuan pembelajaran yang telah direncanakan. Model pembelajaran kooperatif merupakan teknik-teknik kelas praktis yang dapat digunakan guru setiap hari untuk membantu siswa belajar setiap mata pelajaran, mulai dari keterampilan dasar sampai memecahkan masalah yang kompleks (Nur, 2005; Suprijono, 2009; Agustin, dkk, 2013). Dalam pembelajaran kooperatif siswa bekerja bersama dalam 4-6 orang untuk mencapai materi yang diberikan guru. Oleh karena itu pembelajaran kooperatif mengajak peserta didik untuk belajar secara gotong royong dan bekerja sama dalam menyelesaikan suatu masalah, hal ini akan lebih meningkatkan interaksi antar sesama dan membantu peserta didik untuk membina hubungan sosial yang baik dengan rekannya (Ibrahim, 2000; Slavin 2008; Efriza, dkk, 2013).

Menurut Slavin (1995) beberapa kelebihan belajar kooperatif diantaranya, para siswa diberikan kesempatan untuk mendiskusikan masalah, menentukan strategi pemecahannya, dan menghubungkan masalah tersebut dengan masalah-masalah lain yang telah dapat diselesaikan sebelumnya. Dalam proses pembelajaran terjadi interaksi antara guru dengan siswa yang bertujuan untuk mencapai tujuan pembelajaran. Salah satu tujuan pembelajaran adalah diperolehnya hasil belajar yang baik. Hasil belajar yang diperoleh siswa sangat mempengaruhi kualitas dan keberhasilan pembelajaran. Hal ini mengharuskan seorang guru memiliki berbagai macam metode pembelajaran yang digunakan dalam proses pembelajaran. Metode yang digunakan juga harus sesuai dengan tujuan pembelajaran yang membantu guru untuk menyampaikan materi pembelajaran sehingga mudah dipahami siswa sehingga dapat meningkatkan hasil belajarnya. Namun pada kenyataannya masih banyak siswa yang memiliki hasil belajar yang rendah.

Salah satu faktor yang menyebabkan rendahnya hasil belajar siswa tidak terlepas dari peran guru dalam merancang dan menerapkan strategi pembelajaran. Guru mempunyai peranan penting dalam upaya meningkatkan hasil belajar yang diperoleh siswa, karena hasil belajar siswa yang baik menunjukkan keberhasilan siswa dalam melaksanakan proses pembelajaran. Selain itu juga, keberhasilan siswa dalam belajar akan menjadi kebanggaan bagi diri siswa, orang tua maupun lingkungan sekitarnya. Keberhasilan siswa di sekolah ditandai dengan hasil nilai siswa yaitu tingkat ketuntasan minimal (KKM).

Namun proses pembelajaran yang berlangsung saat ini di kelas IV SD No 2 Mengwi belum menggambarkan pembelajaran yang konstruktivitas. Hal ini terlihat dari interaksi siswa yang masih pasif, siswa hanya mencatat dan menerima begitu saja, tidak ada timbal balik berupa komentar atau pertanyaan. Siswa juga masih belajar secara individual dan seakan-akan enggan bekerja sama pada saat siswa berdiskusi, selain itu siswa yang pintar akan mendominasi diskusi itu. Berdasarkan data yang diperoleh oleh peneliti, diketahui bahwa siswa kelas IV 
SD No. 2 Mengwi yang berhasil mencapai KKM (Kriteria Ketuntasan Minimal) IPA yang ditetapkan oleh sekolah hanya berjumlah 12 orang dan siswa yang belum berhasil berjumlah 14 orang dari 26 orang siswa.

Dari fenomena hasil belajar yang diperoleh siswa ini, dilakukan tukar pendapat dengan guru lain untuk mengatasi permasalahan tersebut. Setelah mendapat kesepakatan bersama, maka dicari jalan keluar dengan cara mengidentifikasi permasalahan yang terjadi dengan model pembelajaran yang dapat mengatasi permasalahan yang ada di kelas. Dari sekian banyak model pembelajaran yang ada, model pembelajaran yang relevan mengatasi masalah yang terjadi adalah model pembelajaran kooperatif tipe numbered head together. NHT merupakan salah satu jenis model pembelajaran kooperatif yang dikembangkan oleh Spencer Kagan (1992) untuk melibatkan lebih banyak siswa dalam menelaah materi yang tercakup dalam suatu pelajaran dan mengecek pemahaman mereka terhadap isi pelajaran (Trianto, 2007; Kusumaningtyas, dkk, 2014; Miaz, 2015; Puspa, dkk, 2015, Kurniasih \& Sani, 2015). NHT adalah jenis pembelajaran kooperatif yang dirancang untuk mempengaruhi pola interaksi siswa dan sebagai alternatif terhadap struktur kelas tradisional (Susanto, 2013).

Pembelajaran kooperatif tipe numbered head together dilakukan dengan cara membagi siswa menjadi beberapa kelompok yang beranggotakan 4-5 orang secara heterogen dan kepada setiap anggota kelompok diberi nomor 1 sampai 5 kemudian secara acak guru memanggil nomor dari siswa ( Santyasa dan Sukadi, 2009). Pembelajaran kooperatif tipe NHT merupakan salah satu tipe pembelajaran kooperatif yang menekankan pada struktur khusus yang dirancang untuk mempengaruhi pola interaksi siswa dan memiliki tujuan untuk meningkatkan penguasaan akademik. NHT adalah suatu metode belajar dimana siswa diberi nomor kemudian dibuat suatu kelompok, kemudian secara acak guru memanggil nomor dari siswa.
Tekhnik ini memberikan kesempatan kepada siswa untuk saling membagi bagikan ide dan mempertimbangkan jawaban yang paling tepat. Selain itu, NHT juga meupakan cara yang sangat baik untuk menambah tanggung jawab individual terhadap diskusi kelompok.

Berdasarkan paparan latar belakang di atas perlu dilakukan Penelitian Tindakan Kelas yang berjudul "Penerapan Model Pembelajaran Kooperatif Tipe Numbered Head Together untuk Meningkatkan Hasil Belajar Mata Pelajaran IPA Siswa Kelas IV SD No. 2 Mengwi Tahun Pelajaran 2016/2017".

Rumusan masalah dalam penelitian ini adalah Apakah penerapan model pembelajaran kooperatif tipe numbered head together dapat meningkatkan hasil belajar IPA siswa kelas IV SD No 2 Mengwi tahun pelajaran 2016/2017? Tujuan penelitian ini adalah untuk mengetahui peningkatkan hasil belajar IPA siswa kelas IV SD No. 2 Mengwi tahun pelajaran 2016/2017 melalui penerapan model pembelajaran kooperatif tipe numbered head together.

\section{METODE}

Subjek penelitian ini adalah siswa kelas IV SD N 2 Mengwi yang berjumlah 26 orang. Objek penelitian ini adalah aktivitas dan hasil belajar siswa setelah diterapkan pembelajaran numbered head together. Penelitian ini merupakan penelitian tindakan kelas karena bertujuan untuk memperbaiki kualitas pembelajaran yang bermuara pada peningkatan aktivitas dan hasil belajar siswa. Penelitian tindakan kelas ini dilakukan secara kolaboratif. Pihak yang melakukan tindakan kelas adalah guru itu sendiri, sedangkan yang melakukan pengamatan terhadap berlangsungnya proses tindakan adalah peneliti (Iskandar, 2011; Kunandar, 2010). Penelitian tindakan kelas ini dirancang dalam 2 (dua) siklus. Setiap siklus terdiri dari 3 (Tiga) kali pertemuan. Setiap siklus terdiri dari 4 (empat) tahapan, yaitu perencanaan, pelaksanaan tindakan, observasi/evaluasi, dan refleksi 
(Arikunto, 2010). Tahapan tindakan siklus dijelaskan sebagai berikut.

Perencanaan, kegiatan yang dilakukan pada langkah perencanaan tindakan ini yaitu (1) menentukan materimateri yang dibahas dalam penelitian yang sesuai dengan silabus pembelajaran IPA yang ada, (2) menyiapkan alat dan bahan pembelajaran yang akan digunakan dalam proses pembelajaran, seperti media pembelajaran berupa gambar, buku ajar dan alat-alat tulis, (3) menyusun instrument pengumpulan data aktivitas belajar dan hasil belajar siswa.

Pelaksanaan Tindakan, Setiap tindakan siklus dilaksanakan dalam 3 kali pertemuan.Langkah-langkah kegiatan pembelajaran yaitu 1) Sebelum pembelajaran dimulai, siswa menerima arahan tentang langkah - langkah model pembelajaran kooperatif tipe numbered head together. 2) Guru menjelaskan materi pelajaran secara umum tentang energi dan perubahannya dengan menggunakan media pembelajaran. 3) Guru membagi para siswa menjadi beberapa kelompok atau tim yang beranggotakan 3 hingga 5 orang secara heterogen dan memberi mereka nomor, sehingga tiap siswa dalam tim tersebut memiliki nomor yang berbeda.4) Guru mengajukan beberapa pertanyaan tentang materi yang diajarkan. 5) Berpikir bersama (Head Together) adalah para siswa berpikir bersama untuk menggambarkan dan meyakinkan bahwa tiap orang mengetahui jawaban tersebut. 6) Guru menyebutkan suatu nomor dan para siswa dari tiap kelompok dengan nomor yang sama mengangkat tangan dan menyiapkan jawaban untuk seluruh kelas. 7) Siswa menyiapkan diri untuk menjawab tes evaluasi

Observasi/Evaluasi, selama pelaksanaan tindakan berlangsung, dilakukan observasi terhadap proses pembelajaran secara berkelanjutan. Observasi ini dilakukan untuk mengetahui kesesuaian antara perencanaan dan pelaksanaan tindakan. Observasi yang dilakukan terhadap pelaksanaan penerapan model pembelajaran Numbered Head Togetherdan keseluruhan proses pembelajaran. Hasil observasi ini dicatat dalam bentuk catatan yang berkaitan dengan proses pembelajaran sebagai bahan refleksi. Evaluasi dilakukan pada akhir pelaksanaan tindakan. Hal-hal yang dievaluasi adalah aktivitas dan hasil belajar siswa.

Refleksi, refleksi ini bertujuan untuk merenungkan dan mengkaji hasil tindakan pada kegiatan pembelajaran yang telah dilaksanakan mengenai aktivitas dan hasil belajar siswa. Kemudian berdasarkan hasil refleksi itu, direncanakan tindakan pada siklus berikutnya. Tetapi, jika aktivitas belajar telah mencapai indikator keberhasilan maka penelitian dihentikan.

$$
\text { Metode pengumpulan data }
$$

aktivitas dalam penelitian ini menggunakan metode observasi dan pengumpulan data hasil belajar IPA pada ranah kognitif menggunakan metode tes. Instrumen penelitian yang digunakan untuk pengumpulan data aktivitas dan hasil belajar IPA adalah lembar observasi aktivitas belajar siswa, tes pilihan ganda dan tes essay.

Data aktivitas dan hasil belajar IPA dianalisis secara deskriptif, yaitu dengan menghitung rata-rata (mean) skor aktivitas dan hasil belajar IPA. Hasil perhitungan persentase yang diperoleh selanjutnya data yang diperoleh dikonversikan kedalam PAP skala lima sesuai Tabel 1.

Tabel 1. Pedoman konversi PAP Skala Lima tentang Peningkatan Aktivitas dan Hasil Belajar IPA

\begin{tabular}{cc}
\hline Persentase & Tingkat Hasil BelajarlPA \\
\hline $90-100$ & Sangat tinggi \\
$80-89$ & Tinggi \\
$65-79$ & Sedang \\
$55-64$ & Rendah \\
$0-54$ & Sangat rendah \\
\hline
\end{tabular}


Kriteria keberhasilan adalah standar yang ditetapkan sebagai acuan patokan atau tolak ukur keberhasilan. Penelitian dinyatakan berhasil jika kelas telah mencapai peningkatan persentase aktivitas dan hasil belajar mencapai $85 \%$, pada kategori baik.

\section{HASIL DAN PEMBAHASAN}

Penelitian ini merupakan penelitian tindakan kelas. Subjek penelitian ini adalah siswa kelas IV SD N 2 Mengwi tahun pelajaran 2016/2017 yang berjumlah 26 orang. Mata pelajaran yang digunakan dalam penelitian ini adalah IPA dengan menggunakan model pembelajaran Kooperatif Tipe Numbered Head Together. Setiap siklus dilakukan dalam tiga kali pertemuan yaitu yaitu 2 (dua) kali pertemuan untuk pelaksanaan kegiatan pembelajaran dan 1 (satu) kali pertemuan untuk evaluasi hasil belajar siswa.

Pelaksanaan tindakan siklus I pertemuan pertama dilaksanakan pada tanggal 18 Oktober 2016 dengan materi sumber energi panas kedua dilaksanakan pada tanggal 21 Oktober 2016 dengan materi sumber energi bunyi dan tes hasil belajar IPA dilaksanakan pada tanggal 24 Oktober 2016.

$$
\text { Hasil observasi yang }
$$

dilaksanakan setiap pembelajaran berlangsung, ditemukan bahwa aktivitas belajar dan hasil belajar siswa masih rendah, hal tersebut disebabkan karena dalam melakukan diskusi siswa masih main-main dan hanya mengandalkan satu orang teman saja, siswa masih malu-malu untuk menjawab pertanyaan yang diajukan, dan kurangnya variasi media yang digunakan guru sehingga siswa merasa jenuh dan bosan untuk mengikuti pembelajaran.

Refleksi siklus I yaitu 1) proses pembelajaran pada siklus I secara umum belum dapat berjalan secara optimal sesuai dengan rencana yang diharapkan. Hal ini dapat terjadi karena siswa masih nyaman dengan pola belajar di kelas yang hanya duduk, mendengarkan ceramah dari guru, menulis pernyataanpernyataan penting yang disampaikan oleh guru secara lisan maupun dituliskan di papan tulis, 2) dalam kegiatan tanya jawab, dari 26 orang siswa hanya 19 orang siswa yang mau menjawab pertanyaan guru. Siswa masih merasa malu-malu dan takut salah untuk menjawab pertanyaan yang diberikan, 3) dalam kegiatan diskusi, siswa masih kurang aktif. Hanya 1 sampai 2 orang yang benar-benar mengerjakan tugas yang diberikan dalam kelompoknya. Siswa lainnya sibuk dengan pekerjaannya masing-masing, misalnya mengobrol dan bermain.

Tindakan perbaikan yang diambil untuk mengatasi permasalaha tersebut yaitu 1) untuk membiasakan siswa belajar dengan model yang diterapkan, guru memberikan petunjuk kepada siswa yang belum paham dalam penerapan model pembelajaran numbered head together, 2) untuk membiasakan siswa berani menjawab pertanyaan yang diberikan, guru dapat memberikan reward berupa tepuk tangan dan motivasi kepada siswa pada saat pembelajaran berlangsung, 3) agar siswa aktif dalam kegiatan diskusi, guru dapat mendekati dan memberikan perhatian pada setiap kelompok agar bisa bekerja bersama dalam berdiskusi, dan memberikan motivasi kepada siswa yang kurang aktif.

Pada siklus II pertemuan pertama dilaksanakan pada tanggal 27 Oktober 2016 dengan materi energi alternatifdan penggunaannya, pertemuan kedua dilaksanakan pada tanggal 2 Oktober 2016 dengan materi alat-alat peredaran darah pada manusia. Pelaksanaan pembelajaran pada siklus II sesuai dengan perbaikan pada siklus I. Tes hasil belajar IPA dilaksanakan pada 4 Oktober 2016.

$$
\text { Hasil observasi yang }
$$

dilaksanakan setiap pembelajaran siklus II, ditemukan bahwa dengan penerapan model pembelajaran Numbered Head Together hasil belajar siswa sudah meningkat, hal tersebut terlihat dari keantusiasan siswa ketika guru mengajukan pertanyaan, 24 dari 26 siswa mau menjawab pertanyaan yang 
diajukan guru dan dalam kegiatan diskusi, semua siswa sudah ikut serta dan tekun dalam menyelesaikan tugas yang diberikan oleh guru. Siswa yang awalnya malu-malu untuk menjawab maupun bertanya, setelah penerapan model pembelajaran numbered head together dan memberikan penghargan berupa tanda bintang sudah tidak malumalu untuk menjawab maupun bertanya. Hal tersebut berdampak pula terhadap hasil belajar siswa yang telah memenuhi kriteria keberhasilan.

Segala permasalahan yang terjadi pada siklus I berdasarkan hasil refleksi siklus I relatif sudah teratasi dan hasil belajar siswa telah meningkat dan mencapai kriteria keberhasilan. Penelitian bahkan telah melebihi sehingga penelitian ini dapat dihentikan hingga siklus II. Secara garis besar, pembelajaran sudah sesuai dengan yang direncanakan sebelumnya. Penguasaan materi dan model pembelajaran oleh guru, membuat guru dapat menguasai kelas dengan baik. Siswa yang sebelumnya belum terbiasa belajar dengan menggunakan model pembelajaran, menjadi terbiasa belajar dengan model pembelajaran khususnya model pembelajaran numbered head together, siswa yang mulanya masih merasa malu-malu dan takut salah menjawab pertanyaan yang diberikan sudah berani menjawab pertanyaan yang diberikan dengan baik serta siswa sudah mulai bisa bekerjasama dalam mengerjakan tugas kelompok.

Dari pelaksanaan tindakan yang telah dilakukan dengan penerapan model pembelajaran kooperatif tipe Numbered Head Together (NHT) dapat meningkatkan hasil belajar IPA siswa kelas IV SD No. 2 Mengwi tahun pelajaran 2016/2017 dilihat pada tabel 2.

Tabel 2. Ringkasan Persentase Rata-rata Hasil Belajar IPA pada Siklus I dan Siklus II

\begin{tabular}{lcc}
\hline Tahap & $\begin{array}{c}\text { Persentase Rata-rata Hasil } \\
\text { Belajar IPA }\end{array}$ & Kategori \\
\hline Siklus I & $75,38 \%$ & Sedang \\
Siklus II & $81,34 \%$ & Tinggi \\
\hline
\end{tabular}

Tabel diatas menunjukkan bahwa terjadi peningkatan rata-rata hasil belajar IPA. Pada siklus I rata-rata hasil belajar IPA sebesar $75,38 \%$ mengalami peningkatan pada siklus II sebesar $81,34 \%$ dan sudah memenuhi kriteria keberhasilan yang ditentukan, yaitu $85 \%$. Dengan demikian, siklus dihentikan sampai siklus II.

Model pembelajaran umbered head together menekankan siswa untuk belajar. Pada awal pembelajaran, guru selalu merangsang pikiran siswa agar dapat mengarahkan pikiran siswa ke dalam materi yang akan dipelajari. Pada saat apersepsi guru menggunakan contoh-contoh gambar sehingga mudah dipahami oleh siswa. Selain itu, guru menyampaikan topik serta tujuan pembelajaran agar siswa mengetahui apa yang akan mereka pelajari.

Dalam penerapan model pembelajaran numbered head together, guru kelas IV berkolaborasi dengan peneliti. Saat siswa melakukan proses pembelajaran, guru kelas IV yang dibantu peneliti membimbing kelompok siswa agar setiap kelompok mendapat bimbingan secara merata. Peneliti juga membantu guru kelas IV untuk mengamati kesesuaian antara perencanaan yang telah disusun dan pelaksanaan tindakan yang dilakukan. Hasil penelitian yang telah dilakukan ini menunjukan bahwa penerapan model pembelajaran kooperatif tipe numbered head togetherdapat meningkatkan hasil belajar IPA siswa kelas IV SD No. 2 Mengwi tahun 2016/2017. Berdasarkan hasil penelitian, maka hasil belajar yang diperoleh pada siklus I adalah 75,38\% berada pada kategori sedang. Selanjutnya, hasil belajar siswa pada siklus II adalah $81,34 \%$. Jika dikonversikan berdasarkan PAP skala lima, maka hasil belajar yang diperoleh pada siklus II berada pada kategori tinggi. 
Berdasarkan data di atas, penerapan model pembelajaran kooperatif tipe numbered head together dapat meningkatkan hasil belajar IPA siswa kelas IV SD No. 2 Mengwi tahun 2016/2017. Hasil belajar mengalami peningkatan dari kategori sedang ke kategori tinggi setelah melalui dua siklus. Peningkatan aktivitas dan hasil belajar siswa disebabkan oleh beberapa faktor. Pertama, pelaksanaan proses pembelajaran menggunakan model pembelajaran Numbered Head Together menyebabkan siswa antusias mengikuti pembelajaran. Model pembelajaran ini mengajak siswa terlibat langsung dalam proses pembelajaran. Siswa menjadi lebih tertarik dengan kegiatan yang melibatkan siswa itu sendiri dibandingkan dengan mendengarkan penjelasan dari guru. Siswa diberikan kesempatan untuk berdiskusi dan saling berbagi informasi dalam belajar kelompok, sehingga dapat menumbuhkan interaksi yang aktif antara siswa dengan guru maupun dengan siswa itu sendiri. Hal ini dapat menumbuhkan aktivitas pada siswa, baik sebagai penerima informasi maupun penyampai informasi. Dengan meningkatnya aktivitas siswa, maka meningkat pula hasil belajar siswa. Oleh karena itu hasil belajar tergantung kepada keterlibatan siswa itu sendiri dalam proses pembelajaran.

Faktor kedua adalah guru memberikan kesempatan siswa untuk menyampaikan pendapat, berdiskusi, dan mencari tahu kebenaran dari tugas yang dibuat dengan cara bertanya maupun mengemukakan ide yang mereka miliki. Kegiatan ini membuat siswa menjadi lebih memahami apa yang mereka pelajari karena siswa mencari tahu sendiri kebenaran tugas tersebut. Pembelajaran akan bermakna dengan kegiatan demikian, sehingga hasil belajar siswa pun menjadi meningkat. Penjelasan tersebut sejalan dengan pendapat Slameto (2003) yang menyatakan bahwa dalam interaksi belajar mengajar, guru harus banyak memberikan kebebasan kepada siswa untuk menyelidiki sendiri, mengamati sendiri, belajar sendiri, dan mencari pemecahan masalah sendiri. Kegiatan ini dapat menumbuhkan rasa percaya diri pada diri siswa dan tidak selalu menggantungkan diri pada orang lain. Dampaknya adalah hasil belajar siswa menjadi lebih baik.

Ketiga, penggunaan media pembelajaran memudahkan siswa untuk memahami materi pembelajaran. Media pembelajaran dapat meningkatkan minat dan memotivasi siswa, sehingga siswa akan lebih bersemangat dan berperan aktif untuk mengikuti proses pembelajaran. Media pembelajaran juga dapat membantu siswa menyerap materi yang dipelajari lebih mendalam dan utuh.

Faktor yang terakhir adalah pemberian penghargaan (reward). Ketertarikan siswa untuk belajar juga tergantung pada langkah guru memberikan penghargaan atau hadiah untuk membuat siswa lebih bersemangat mengikuti pembelajaran. Siswa menjadi antusias setelah diberikan penghargaan berupa tepuk tangan dan tanda bintang. Hal ini membuat siswa termotivasi untuk lebih aktif selama proses pembelajaran. Siswa akan termotivasi untuk meningkatkan usaha dalam kegiatan belajar dengan penghargaan berupa tanda bintangsehingga dapat meningkatkan hasil belajar siswa. Hal tersebut sejalan dengan pendapat Slameto (2003) yang menyatakan bahwa jika reward yang diberikan dengan tepat, dapat mengakibatkan siswa mempunyai sikap yang positif dan meningkatkan motivasi siswa. Siswa menjadi terdorong untuk melakukan usaha dalam mencapai tujuan belajar yang diinginkan. Pemberian reward dapat dimanfaatkan untuk memotivasi belajar siswa, yang berorientasi pada keberhasilan belajar siswa. Penjelasan yang sejalan juga dinyatakan oleh Uno (2008) yang menyatakan bahwa semakin tinggi motivasi siswa dalam belajar, maka hasil belajar siswa juga akan semakin tinggi.

Berdasarkan uraian tersebut, penelitian ini dikatakan telah berhasil karena kriteria yang diterapkan sebelumnya telah terpenuhi. Jadi, dapat diinterpretasikan bahwa penerapan model pembelajaran kooperatif tipe numbered head together dapat 
meningkatkan hasil belajar IPA siswa kelas IV SD No. 2 Mengwi tahun 2016/2017.

\section{SIMPULAN DAN SARAN}

Kesimpulan dalam penelitian ini adalah Penerapan model pembelajaran kooperatif tipe numbered head together dapat meningkatkan hasil belajar IPA siswa kelas IV SD No 2 Mengwi. Pada siklus I ketuntasan belajar siswa mencapai $75,38 \%$, dimana pada siklus I siswa yang tuntas hanya berjumlah 18 orang, dengan rata - rata hasil belajar siswa sebesar 75,38. Dari siklus I ke siklus II ketuntasan belajar siswa mengalami peningkatan sebesar $5,97 \%$ yaitu $81,34 \%$ dengan rata - rata hasil hasil belajar siswa sebesar 81,35. Maka dapat dinyatakan bahwa penerapan model pembelajaran kooperatif tipe numbered head together dapat meningkatkan hasil belajar IPA siswa kelas IV SD No 2 Mengwi.

Saran yang dapat disampaikan berdasarkan hasil penelitian tindakan ini adalah 1) Bagi sekolah, penelitian ini dapat dijadikan sebagai pedoman dalam pembelajaran IPA dan juga pembelajaran ilmu-ilmu lain guna meningkatkan aktivitas dan hasil belajar siswa, 2) Bagi guru, diharapkan agar guru IPA kelas IV dapat menerapkan model pembelajaranKooperatif Tipe Numbered Head Together (NHT) dalam pembelajaran sebagai suatu alternatif dalam inovasi pembelajaran. Hal ini perlu dilakukan karena penerapan model pembelajaranKooperatif Tipe Numbered Head Together (NHT) dapat meningkatkan hasil belajar IPA siswa, 3) Bagi siswa, diharapkan kepada siswa kelas IV SD NO. 2 Mengwi agar pada saat mengikuti pelajaran IPA dengan diterapkannya model pembelajaran Kooperatif Tipe Numbered Head Together (NHT) telah menyiapkan diri baik secara fisik maupun mental sehingga pembelajaran di kelas dapat berlangsung optimal yang nantinya akan dapat meningkatkan aktivitas dan hasil belajar siswa.

UCAPAN TERIMA KASIH
Dalam proses pembuatan skripsi ini, banyak bantuan yang diperoleh dari berbagai pihak. Oleh karena itu, pada kesempatan ini diucapkan terima kasih kepada yang terhormat Drs. I Ketut Dibia, S.Pd.,M.Pd yang selama ini telah memberikan arahan dan bimbingannya.

\section{DAFTAR PUSTAKA}

Agung, A.A. Gede. 2010. Metodologi Penelitian Pendidikan. Suatu Pengantar. Singaraja: Fakultas Ilmu Pendidikan Institut Keguruan dan IImu Pendidikan Negeri Singaraja.

Agustin, Setya \& Aryanto, Sugeng. Antara, Sukma. 2013. The Effect Of Using Numbered Head Together Technique On The Eighth Grade Students' Reading Comprehension Achievement At Smpn 2 Tanggul Jember Jurnal Pancaran. 2 (3). 201-210.

Arikunto, Suharsini. 2010. Prosedur Penelitian Suatu Pendekatan Praktik. Jakarta : Rineka Cipta.

Arini. 2009. Pembelajaran Kooperatif Model Jigsaw. Tersedia pada http://yusti-

arini.blogspot.com/2009/08/model -pembelajaran-kooperatif.html (diakses tanggal 17 Februari 2013).

B. Uno, Hamzah. 2008. Teori Motivasi dan Pengukurannya, Jakarta : Bumi Aksara

Dimyanti \& Mudjiono. 1992. Strategi Belajar Mengajar. Jakarta : Depdikbud.

Hakim, Timorida Maliani. 2008. Pengaruh Penggunaan Model Pembelajaran Kooperatif Tipe Teams Games Tournaments (TGT) Berfasilitas Media Power Point Terhadap Hasil Belajar TIK Siswa Kelas VIII di SMP Negeri 3 Banjar Tahun Ajaran 2008/2009. Singaraja. Tidak diterbitkan.

Ibrahim, M. 2000. Pembelajaran Kooperatif. Surabaya : University Press. 
Iskandar. 2011. Penelitian Tindakan Kelas. Jakarta : Gaung Persada.

Kunandar. 2010. Penelitian Tindakan Kelas sebagai Pengembangan Profesi Guru.Jakarta : Rajawali Pers.

Kurniasih, Imas \& Berlin Sani. 2015. Ragam Pengembangan Model Pembelajaran Untuk Peningkatan Profesionalitas Guru. Jogjakarta: Kata Pena.

Kusumaningtyas, Y. P., \& Kusmayadi, T. A. (2014). Eksperimentasi Model Pembelajaran Think Talk Write ( Ttw ) Dan Numbered Head Together ( Nht ) Terhadap Prestasi Belajar Matematika Ditinjau Dari Konsep Diri Belajar Matematika Siswa Di Smp Negeri E-Kabupaten Blora. Jurnal Elektronik Pembelajaran Matematika 2(2), 215-225.

Miaz, Y. (2015). The Implementation Of Numbered Heads Together To Improve The Students' Achievement Of Social Sciences In Primary School. Research Journal of Social Sciences. 8 (10). 40-45.

Nur, Mohamad. 2005. Pembelajaran Kooperatif.Surabaya : Pusat Sains dan Matematika Sekolah UNESA.
Puspa, D., Danti, N., Suprayitno, I. J., Prihaswati, M., Konstruktivisme, P., \& Belajar, P. (2015). Perbandingan Pembelajaran Number Head Together Dengan Team Assisted Individualization Berpendekatan, 2(April). JKPM. 2 (1). 15-21.

Santyasa, I Wayan dan Sukadi. 2009. "Model - model Pembelajaran Inovatif" Makalah disajikan dalam pendidikan dan Latihan Profesi Guru (PLPG) Undiksha. Singaraja : Tidak diterbitkan.

Slameto. 2003. Belajar dan Faktor Faktor Yang Mempengaruhinya. Jakarta : PT Rineka Cipta.

Slavin, R.E.. 1995. Cooperative Learning. Allyn \& Bacon. A Simon \& Aschuster Company.

------. 2008. Cooperative Learning (Teori, Riset dan Praktek). Bandung: Nusa Media

Suprijono, Agus. 2009. Cooperative Learning Teori \& Aplikasi Paikem. Surabaya: Pustaka Pelajar.

Susanto, Ahmad. 2013. Teori Belajar \&Pembelajaran di Sekolah Dasar. Jakarta: Kencana Prenada

Trianto. $2007 . \quad M o d e l-m o d e l$ Pembelajaran Inovatif Berorientasi Konstruktivistik. Jakarta:Prestasi Pustaka. 